Another Day, Another Dollar: Enterprise Resilience Under Terrorism in Developing Countries

\author{
Oana Branzei
}

$\&$

Samer Abdelnour ${ }^{\mathrm{i}}$ 


\title{
Another Day, Another Dollar: Enterprise Resilience Under Terrorism in Developing Countries
}

\begin{abstract}
This study extends the literature on entrepreneurship in developing countries by offering a twostage explanation for the paradoxical observation that enterprise activities often flourish under extreme adversity. Our findings complement the base-of-pyramid and peace-through-commerce attention to the growing role of business in international development by fleshing out the functions of enterprise resilience under terrorism. We first explain how terrorism conditions (outbreak, escalation, and reduction) may create psychological incentives for enterprise resilience; then we show that, controlling for ex ante terrorism conditions, enterprise resilience yields more favorable economic payoffs at higher levels of terrorism, especially for informal entrepreneurs.
\end{abstract}

Keywords: entrepreneurship in emerging markets; economic development; market turmoil; lowincome markets; bottom of the pyramid; peace-through-commerce; international development 


\section{INTRODUCTION}

People dream, hope and achieve even in the direst of circumstances. Enterprise has an extraordinary power of emancipation for people living in deep poverty (Seelos \& Mair, 2007). Mahajan and Banga (2006) estimate that $86 \%$ of the world's 6 billion inhabitants live in countries with a per capita gross national product of less than $\$ 10,000$. Enterprise is endemic in developing countries (Rangan, Quelch, Herrero, \& Barton, 2007). In some settings, small family business accounts for more than 95\% of the workforce (Casillas, Acedo, \& Moreno, 2007); women own or operate between onefourth and one-third of small and medium enterprises (SMEs) in the world (Smith-Hunter, 2006). Informal (Webb, Tihanyi, Ireland, \& Sirmon, 2009) and lesser-educated (Yunus, 1998) entrepreneurs can also create and exploit lucrative opportunities, crafting paths out of poverty for themselves and their families (de Soto, 1989, 2000).

The literature on entrepreneurship in developing countries, as well as the broader international entrepreneurship literature, has so far paid only limited attention to the poor and especially the marginalized entrepreneur (e.g., women, Ayadurai \& Sohail, 2006; informal sector participants, de Soto, 1989; or the lesser educated, Yunus, 1998). This is despite growing evidence that entrepreneurship plays an important role in creating social and economic value in subsistence market settings (Abdelnour \& Branzei, 2009a; Cross \& Morales, 2007;Weiser, Kahane, Rochlin, \& Landis, 2006).We broaden the notion of the entrepreneur, central in international entrepreneurship research (McDougall, Shane \& Oviatt, 1994), to draw greater attention to the incidence and persistence of entrepreneurship under poverty, adversity and conflict. We do so by marrying the peace-through-commerce literature's predictions about how business helps the poor overcome disruptions with the base-ofpyramid (BOP) emphasis on economic incentives to business - large (Prahalad, 2004) or small (London, 2009) - in developing countries.

Peace-through-commerce scholars argue that business plays an important role in post-conflict stabilization, reconstruction and peace-building (Fort \& Schipani, 2004; Wenger \& Mo"ckli, 2003). Although most peace-through-commerce studies advocate greater engagement by multinational enterprises in the peace-building process (Williams, 2008), research on the role of enterprises and entrepreneurship is gaining momentum (Gerson \& Colletta, 2002). Economic (re)engagement in micro- and small enterprises helps sustain livelihoods in times of turmoil (SEEP, 2007) and structural upheaval (Honig, 2001). Conflict can also emancipate marginalized actors into entrepreneurial roles (Fadahunsi \& Rosa, 2002). Some "envision and respond to the ebb and flow of social conflict as life-giving opportunities for creating constructive change processes that reduce violence, increase justice in direct interaction and social structures, and respond to real-life problems" (Lederach, 2003: 14). Yet we know little about what may motivate entrepreneurs in developing countries to (re)engage in economic activities - especially in the aftermath of emergencies, crises and political disruption (Abdelnour \& Branzei, 2009b; Cross \& Morales, 2007; MacSweeney \& Tanburn, 2008).

For BOP researchers, the poor represent an untapped market segment where multinational enterprises can create "fortunes" (Hammond, Kramer, Robert, Tran, \& Walker, 2007; Prahalad, 2004), at times at the cost of "misfortunes" for local market participants (Karnani, 2007; Walsh, Kress \& Beyerchen, 2005). BOP studies focus largely on the economic payoffs to corporate and international ventures in emerging-market settings (Simanis et al., 2008). They acknowledge the 
social benefits of grassroots ventures in the BOP space (i.e., empowerment, legitimacy, and social transformation; Lodge \& Wilson, 2006; London, 2009) as complementary to their contribution to economic value creation (Weiser et al., 2006; Wilson \& Wilson, 2006). However, the BOP literature remains largely silent on the emergence and persistence of enterprise under extreme poverty (Seelos \& Mair, 2007) or adversity (Honig, 1998).

The (still) limited overlap between the peacethrough- commerce and BOP literatures speaks to a growing disconnect between the focus of international entrepreneurship research and the growing numbers and social and economic importance of the poor and the marginalized entrepreneurs in subsistence marketplaces (Cross \& Morales, 2007; London, 2009). International entrepreneurship, broadly defined as "the recognition, discussion, evaluation, and exploitation of opportunities across national limits - to create future goods and services" (Oviatt \& McDougall, 2005: 540), provides rich predictions about how globalization helps or hinders economic value creation by SMEs. However, discussion of the pro-social and pro-peace functions of enterprise remain notably missing, despite growing agreement that in developing countries these functions are important in their own right (Abdelnour \& Branzei, 2009a) and can facilitate value creation (Wilson \& Wilson, 2006).

With only a handful of exceptions (e.g., Fadahunsi \& Rosa, 2002; Honig, 1998), the causes of, contingencies to, and returns to entrepreneurship among the poor in developing countries remain unexplored. This research gap is wider for marginalized entrepreneurs and/or the poor in developing countries. Recent studies call greater attention to the role of women entrepreneurs (Cala's, Smircich, \& Bourne, 2009; Salway, Rahman, \& Jesmin, 2003; Sethuraman, 1998), informal entrepreneurs (Bacchetta, Ernst, \& Bustamante, 2009; Webb et al., 2009), and lesser-educated entrepreneurs (Yunus, 1998). We know comparatively much less about the many entrepreneurs coping with the adverse consequences of globalization (Griffith, Cavusgil, \& Xu, 2008) than we do about the thriving SMEs sprawling across international boundaries (Wright, Filatotchev, Hoskisson, \& Peng, 2005; Zahra, Ireland, \& Hitt, 2000).

We know notably little about the paradox of enterprise emergence and persistence under adversity. A handful of prior studies observed greater entrepreneurial activity after economic shocks (Skoufias, 2003), disasters (Tang, 2006), conflict (SEEP, 2007), and war (El Jack, 2007), yet theoretical and empirical research on the incidence and persistence of enterprise under terrorism remains limited.

\section{ENTERPRISE RESILIENCE UNDER TERRORISM}

This study explores enterprise resilience under terrorism. The 1999 United Nations' International Convention for the Suppression of the Financing of Terrorism defines terrorism as "any act intended to cause death or serious bodily injury to a civilian, or to any other person not taking an active part in the hostilities in a situation of armed conflict, when the purpose of such acts, by their very nature or context, is to intimidate a population, or compel a government or an international organization to do or to abstain from doing any act" (Article 2b, quoted by Vázquez, Pérez-Sales, \& Hervás, 2008: 64).

Poverty is commonly understood as "the root cause" of terrorism (Smith, 2008: 184) and protracted conflict (Oberschall, 2007). Economic development can "address the underlying roots of 
the open violence in ways that more systematically redress fundamental patterns of injustice, particularly in the arena of poverty and economic disparity" (Lederach, 2008: 100-101). It can also offer an antidote to terrorism by eliminating or modifying the conditions that have produced discontent. We focus on economic (re)engagement through enterprise - defined as entry into new products and markets and/or new businesses, whether though the creation of a new firm or via existing firms (Lumpkin \& Dess, 1996).

\section{Intended Contribution}

We contribute a two-stage argument. We first draw on positive psychology predictions about overcoming sudden shocks, coping with persistent adversity, and hoping for a better future to explain how entrepreneurship may vary across terrorism conditions. Our working hypothesis is that people can overcome the disruption caused by terrorism by developing psychological resilience (Joseph \& Linley, 2008; Tedeschi \& Calhoun, 2004; Val \& Linley, 2006). We then discuss why and when enterprise is resilient to terrorism. We argue and show that entrepreneurs earn comparatively more than non-entrepreneurs across terrorism conditions, and informal and lessereducated entrepreneurs have lesser economic disincentives relative to formal and more-educated entrepreneurs at higher levels of terrorism.

\section{Research setting}

We focus on enterprise resilience in urban slums. The combination is neither uncommon nor trivial. United Nations Habitat (2003) estimates that 924 million, or $31.6 \%$ of the world's urban population, lived in slums in 2001, and the United Nations Department of Economic and Social Affairs (2004) estimates that 2 billion people, or one fifth to one quarter of the world's population, will probably consist of urban poor living in slums or slum-like conditions by 2030. Urban slums are at high risk for different kinds of conflict (Smith, 2008), including civil unrest, ethnic clashes, and terrorist events (Smith, 2008). The twin phenomena of slum sprawl and domestic political terrorism are common across South Asia, and yield growing global relevance (Smith, 2008). Both the conditions and the level of terrorism vary across urban slums in Bangladesh (Chowdhury, 2003; Kumaraswamy, 2007), providing an optimal empirical setting for understanding how terrorism may influence enterprise resilience in developing countries. Our empirical findings are based on single-country tests. The relationship between terrorism and enterprise resilience holds broader theoretical implications for marginalized entrepreneurs across developing countries, especially the poor in urban slum settings.

\section{THEORY AND HYPOTHESES}

Figure 1 summarizes our theoretical framework of enterprise resilience under terrorism. We first explain how different terrorism conditions influence enterprise resilience (Hypothesis 1), contingent on entrepreneurs' gender (Hypothesis 2). Then we predict economic returns to enterprise resilience (Hypothesis 3), contingent on entrepreneurs' informality (Hypothesis 4) and education (Hypothesis 5), across different conditions and levels of terrorism. 
Insert Figure 1 About Here

\section{Terrorism Conditions}

One explanation for the paradoxical observation that enterprises often flourish under extreme adversity relies on positive psychology predictions that disruption, shock, and trauma may encourage (re)engagement in enterprise activities (Richardson, 2002). Here we focus on enterprise resilience under three distinct terrorism conditions: outbreak, escalation, and reduction. We argue that terrorism outbreak hones coping skills in the face of unexpected adversity (Waugh, Fredrickson, \& Taylor, 2008), that terrorism escalation may enable posttraumatic growth (Bonanno, Galea, Bucciarelli, \& Vlahov, 2007; Westphal \& Bonanno, 2007), and that terrorism reduction instills hope (Garlan, Butler, \& Spiegel, 2005).

Terrorism outbreak. The notion of striving under adversity has been foundational in entrepreneurship research: entrepreneurs have a higher adversity quotient than nonentrepreneurs (Baron \& Markman, 2000). They are more likely to remain optimistic in the face of adversity (Markman, Baron, \& Balkin, 2005); they are also more likely to take action to counteract unexpected stressors (Morland, Butler, \& Leskin, 2008). Adversity can also be a hotbed of opportunity (Aidis \& van Praag, 2007; Fadahunsi \& Rosa, 2002). By flagging lucrative incongruences and opening up transitional opportunities (Webb et al., 2009), tough times often "incubate" entrepreneurs (Ayadurai \& Sohail, 2006; Honig, 2001). Setbacks can also stimulate counterfactual thinking and enable opportunity creation through lucrative resource reconfigurations (Branzei \& Peneycad, 2008). As individuals cope with sudden distress, they build psychological and social capital (Hmieleski \& Carr, 2007), which are strong predictors of economic (re)engagement through enterprise across post-disaster contexts (SEEP, 2007).

Hypothesis 1a: For urban slum dwellers in developing countries, terrorism outbreak is positively associated with enterprise resilience.

Terrorism escalation. When adversity escalates, individuals are more likely to search for meaning and develop a sense of agency in spite of the trauma - that is, coming to an understanding that "they were strong and resourceful in ways that they had not previously known, and an appreciation that this self-knowledge would serve them well in the future" (Maitlis, 2009: 69). Westphal and Bonanno (2007: 418) highlight the silver lining of psychological trauma: experiencing traumatic events can help some people "grow toward more optimal functioning". Linley and Joseph (2004: 11) further emphasize that the mere "process of struggling with adversity [may] propel the individual to a higher level of functioning than that which existed prior to the event." Studies of economic (re)engagement following peace processes in Northern Ireland, Bosnia, Israel and Palestine (Oberschall, 2007), interventions in Iraq, responses to the humanitarian crises in Rwanda 
and Sudan (Jacoby, 2008), and mobilization to action in the aftermath of recent terrorist events in the US, Spain, the UK, and India (Vázquez, Cervellón, Pérez-Sales, Vidales, \& Gaborit, 2005) suggest that post-traumatic growth can encourage agency through enterprise activities.

Hypothesis 1 b: For urban slum dwellers in developing countries, terrorism escalation is positively associated with enterprise resilience.

Terrorism reduction. A reduction in terrorism offers a glimmer of peace and security - bringing forth hope for a better quality of life in the future (Lederach, 2008). A reduction in terrorism replaces negative emotions, such as fear, with positive emotions, such as hope and joy. Positive emotions improve the odds of overcoming and removing constraints (Fredrickson, 2006: 96-97). While fear narrows thinking and helps people continue along a prior line of thinking or action, positive emotions broaden mindsets and motivate exploration, experimentation and engagement (Fredrickson, Tugade, Waugh, \& Larkin, 2003). Endemic entrepreneurship under extreme adversity often starts with the mere imagination of a better future (Davis, 2006; de Soto's poignant "paths out of poverty," 2000). The vision of a better future reinstates the right to the pursuit of happiness (Lindner, 2009). Enterprise activities represent a means to this greater end. Enterprise emancipates (Rindova, Barry, \& Ketchen, 2009): entrepreneurs first imagine, and then build, a better future for themselves and their families.

Hypothesis 1c: For urban slum dwellers in developing countries, terrorism reduction is positively associated with enterprise resilience.

\section{Gender and Terrorism Conditions}

Women typically face greater barriers to entrepreneurship in both developed (Lerner, Brush \& Hisrich, 1997) and developing contexts (Sethuraman, 1998; Shehabuddin, 2004) - yet they are comparatively more likely to emerge as entrepreneurs under adversity and conflict (Smith-Hunter, 2006), after disasters (Bonanno et al., 2007) or disruption (Fadahunsi \& Rosa, 2002), and during systematic upheaval (Honig, 1998). Women may also respond more strongly than men to different terrorism conditions.

First, women entrepreneurs may be more resilient than men following sudden terrorism outbreaks. When necessity pushes them into entrepreneurial roles, women are opportunity-orientated, resourceful and highly motivated (Langowitz \& Minniti, 2007). Intervention programs often target women and thus tend to asymmetrically improve their ability to cope with unexpected difficulties and setbacks (SEEP, 2007).

Second, women entrepreneurs may be more resilient than men when terrorism escalates. Although pervasive or stable differences in how genders adapt to adversity are "too early to call" (Tennen \& Affleck, 1998: 89), there is some evidence that women adapt more swiftly to traumatic experiences (Vrana \& Lauterbach, 1994). Life narratives of women (re)engaging in economic activities in the aftermath of major disruptions and humanitarian crises speak to women's comparatively higher 
propensity to seek meaning and purpose in distressing situations, and to rethink and adjust their roles and responsibilities (El Jack, 2007; Nelson, 2000).

Third, a reduction in terrorism may encourage greater enterprise resilience for women than men because the post-conflict transition to more inclusive, dignified, and equalitarian approaches often levels the playing field for previously marginalized groups in general (Lindner, 2009) and women in particular (Ayadurai \& Sohail, 2006). Transitions from conflict to stability often create greater opportunities for emancipation for women (El Jack, 2007). Women may also be more likely than men to take advantage of these opportunities because they are more attuned to social change (Cala's et al., 2009) and quicker to adjust their roles in response to social changes (de Bruin, Brush, \& Welter, 2007: 334).

Hypothesis 2: For urban slum dwellers in developing countries, gender moderates the effects of terrorism conditions on enterprise resilience, such that (a) terrorism outbreak, (b) terrorism escalation, and (c) terrorism reduction have a stronger positive effect for women than men.

\section{Enterprise Resilience}

We have already explained how ex ante terrorism conditions influence enterprise resilience by describing psychological mechanisms of positive adaptation to terrorism outbreak, escalation, and reduction. We now turn to the logical next question and ask why and when enterprise activities may be an economically rational choice in the aftermath of terrorism. Our working hypothesis is that enterprise activities generate higher economic returns than alternative employment opportunities across terrorism conditions (Hypothesis 3). We further argue that enterprise activities may become comparatively more attractive to informal (Hypothesis 4) and lessereducated entrepreneurs (Hypothesis 5), because higher levels of terrorism reduce the economic penalty to informality (de Soto, 1989) and the education premium (Yunus, 1998).

Terrorism not only disrupts the normal course of life and business, but also motivates individuals (Honig, 2001) and communities (Peredo \& Chrisman, 2006) to take steps to overcome or mitigate risk (SEEP, 2007). South Africa's emergence from the apartheid years was partially credited to an outburst in entrepreneurial activity: Aymes (1989) found a business operating in every fifth township house; about one-third of these ventures employed at least one family member. Entrepreneurial activity is endemic and often scales up under constraint (Fadahunsi \& Rosa, 2002) and crisis (Honig, 2001). It also provides a sensitive indicator of the local resolve to recover from the destruction and disruption caused by terrorist events - the November 2008 Mumbai attacks, the 2005 London and 2004 Madrid train bombings, and the recurrent attacks in Gaza are telling examples.

The most straightforward explanation for the paradox of enterprise resilience in the face of adversity is that returns to entrepreneurial activities are commensurate with risk (Azevedo, 2005). Entrepreneurs incur significantly higher levels of personal and business risk, and thus should rationally expect to earn greater returns (Aidis \& van Praag, 2007; Fadahunsi \& Rosa, 2002). Returns to enterprise activities have been elusive in times of adversity, when the nature and frequency of payments become less predictable (Honig, 2001). Payoffs tend to be particularly unreliable for enterprises in the informal sector (Azevedo, 2005; Mead \& Morrisson, 1996). 
Furthermore, differences in the nature and timing of payments across different occupations entrepreneurial and nonentrepreneurial - make economic payoffs to economic activities hard to quantify and compare. Nevertheless, in lower-income settings such as urban slums in developing countries, income is accurately reflected in the nutritional intake of the household, especially in the meals provided to their children (Carter \& Maluccio, 2003). We heed the recommendation of several prior studies and use household nutritional intake as a proxy for income in times of adversity (Carter \& Maluccio, 2003), natural disasters (del Ninno, Dorosh \& Smith, 2003), and economic crises (Skoufias, 2003). Entrepreneurs can earn greater returns than nonentrepreneurs across levels of terrorism because they are more likely to recognize, devise, and implement timely and innovative responses to crises (MacSweeney \& Tanburn, 2008). Because they can draw on alternative sources of inputs and labor, they are also better positioned to overcome temporary paralysis (Lederach, 2008) and to find or create lucrative opportunities in and around the disruption (Fadahunsi \& Rosa, 2002). Enterprise activities accelerate post-conflict recovery both directly (e.g., by restoring socio-economic exchanges; Fadahunsi \& Rosa, 2002) and indirectly (e.g., by fostering local experimentation, self-sufficiency, and talent; Lederach, 2008).

Hypothesis 3: For urban slum dwellers in developing countries, greater enterprise resilience is associated with higher levels of income.

\section{Informality}

Informality is common in developing countries (Webb et al., 2009), and is especially prevalent in urban slum settings (Davis, 2006). Informality is typically legitimate within the community (Webb et al., 2009) because it offers paths out of poverty (de Soto, 2000) and contributes to socioeconomic development (SEEP, 2007). We focus on legitimate informal enterprises in Bangladeshi urban slums. Bangladesh has a culture largely supportive of entrepreneurial pursuits, and a rapidly emerging socio-economic infrastructure. Grameen Bank and BRAC,1 two of the world's most successful templates for large-scale human development and empowerment through microenterprise, first emerged in Bangladesh. The informal sector also encompasses illegal but legitimate activities, such as trading goods across closed national boundaries (Aidis \& van Praag, 2007; Fadahunsi \& Rosa, 2002) and illegal and llegitimate activities, such as trafficking drugs and arms (Goodhand \& Hulme, 1999). Illegitimate informality is neither common nor systematic in Bangladesh (Azim, 2008), or in urban slums more broadly (Davis, 2006).

Informality tends to be more prevalent in times of adversity and conflict. Informal enterprise helps sustain families in times of crisis (Carter \& Maluccio, 2003; Skoufias, 2003) by providing employment and income (Azevedo, 2005). Informality is functional, because it enables the recognition and exploitation of lucrative opportunities in spite of, and at times because of, inadequate economic, political, and cultural institutional arrangements (Webb et al., 2009). However, informality incurs financial penalties: informal entrepreneurs often earn less and incur higher costs (Davis, 2006) than formal entrepreneurs. The exact penalty for informality has rarely been quantified, owing to a paucity of rigorous measurement of informal activity. Nevertheless, there is little disagreement that the informality penalty remains pervasive and problematic (Azevedo, 2005; Mead \& Morrisson, 1996). 
One explanation for the incidence and persistence of informal enterprises across terrorism conditions is that higher levels of terrorism may lessen the economic penalty for informality by reducing the earnings gap between formal and informal enterprises (Webb et al., 2009). Terrorism may be comparatively less disruptive to informal enterprises, which tend to rely on socially embedded exchanges, than to formal ventures, whose greater dependence on economic infrastructure may temporarily stall their activities or raise their costs during post-conflict interventions (Williams, 2008). Adversity may also temporarily shift demand away from premium goods and towards lower-cost survival goods, indirectly transferring returns from formal to informal enterprises.

Hypothesis 4: For urban slum dwellers in developing countries, the negative effect of informality on income is weaker at higher levels of terrorism.

\section{Education}

Education has a robust positive association with venture launch and success in both developing (Manolova, Carter, Manev, \& Gyoshev, 2007) and developed contexts (Lerner, Brush, \& Hisrich, 1997). Education is a critical predictor of enterprise resilience in developing countries (Van der Sluis, van Praag, \& Vijverberg, 2005), especially for informal (Yunus, 1998) and microentrepreneurs (Honig, 1998). Lack of education does not discourage entrepreneurs from trying (Aidis \& van Praag, 2007; Fadahunsi \& Rosa, 2002); nor does additional education always encourage entrepreneurship (Nelson, 2000). However, lack of education has been long decried as a persistent contributor to poverty (Yunus, 1998) and a barrier to economic reengagement (SEEP, 2007), especially in the aftermath of conflict (Nelson, 2000). There is also evidence of an education premium. Because education improves entrepreneurs' self-confidence (Langowitz \& Minniti, 2007), optimism (Markman et al., 2005), and psychological capital (Hmieleski \& Carr, 2007), it helps them better identify, create, and/or exploit opportunities, and thus yields comparatively greater economic returns (MacSweeney \& Tanburn, 2008).

Higher levels of terrorism may lessen this education premium, because the disruption of former socio-economic structures (Honig, 2001) and their replacement with new ways of doing business (Abdelnour \& Branzei, 2009b) may temporarily change the payoffs to education, so that educated entrepreneurs may have a lesser advantage in identifying and exploiting opportunities, while uneducated entrepreneurs may be at a lesser disadvantage (Fadahunsi \& Rosa, 2002).

Hypothesis 5: For urban slum dwellers in developing countries, the positive effect of education on income is weaker at higher levels of terrorism. 


\section{METHOD}

\section{Research design}

We used a natural experiment design that spanned a 4-year window (February 2001-January 2005), reconstructed from multiple archival sources that reported on local terrorist events in the six largest Bangladeshi cities ${ }^{2}$. We started with the Terrorism Knowledge Base (TKB) developed by the Memorial Institute for the Prevention of Terrorism (MIPT), and extracted detailed information on each terrorism event, including date, location, and reported number of fatalities and injuries. MIPT cross-checks all the TKB incident summaries against reports by several organizations, including academic institutions, private monitor groups and a US federal government agency. We verified the completeness of the TKB reports by triangulating the records extracted from the TKB against both local and international media sources.

Natural experiment groups. Comparing the incidence of terrorist events between the first 2 years (February 2001-January 2003) and the next 2 years (February 2003-January 2005) yields four natural experiment conditions. Terrorism was absent in two cities, Rajshahi and Barisal, which were spared any terrorist attacks during the 4-year window period. Two other cities, Khulna and Sylhet, witnessed a terrorism outbreak: they had no terrorism incidents in the first 2-year period, but experienced a sudden onset of terrorist events in the following 2-year period. Bangladesh's two largest cities, Dhaka and Chittagong, had terrorist events in the first 2-year period and saw respectively an increase and a decrease in terrorism events in the next two (see Appendix).

Level of terrorism. We operationalized the level of terrorism using the standardized composite measure of intensity, frequency, and scope recommended by Ross (1993) for political terrorism. We measured the level of terrorism during the 2 years following the terrorism outbreak, escalation or reduction, that is, from February 2003 to January 2005. Intensity describes the value conflicting actors place on their goals (Jacoby, 2008). Terrorism intensity was computed as the average number of casualties per incident, measured as the total number of casualties (fatalities and injuries) divided by the number of incidents reported within each city (Blomberg, Hess, \& Orphanides, 2004). In our study, the average casualty count per event from February 2003 to January 2005 was 24.5 dead or injured. Frequency refers to the magnitude and pace at which conflict unfolds (Jacoby, 2008). Terrorism frequency was measured as the total count of incidents reported. It was highest in Dhaka (26 events overall, 16 from February 2003 to January 2005), and lowest in Chittagong (1 event); Khulna witnessed nine terrorist events and Sylhet five, all occurring between February 2003 and January 2005. Scope generally describes the extent of the setback for a specific audience, such as the number of goals thwarted or the extent of the disruption experienced (Jacoby, 2008: 19). We proxied terrorism scope by the number of days between the latest occurrence of terrorism in each of the four municipalities afflicted until the end of our terrorism data collection, January 2005: 4 days in Sylhet, 162 days in Dhaka, 188 days in Khulna, and 1091 days in Chittagong. Terrorism intensity, frequency, and scope had an average inter-item correlation of 0.92. Cronbach's alpha for the composite measure was 0.94 . 


\section{Sample}

For each conflict condition we obtained detailed household-level data from the Nutritional Surveillance Project (NSP) of Helen Keller International (HKI) in Bangladesh for February 2005January 2006, so that both the conditions and levels of terrorism were lagged by 1 year from our primary measures of enterprise activities (i.e., resilience, informality, and education) and their payoffs (i.e., income). HKI's NSP provides an independent source of high-quality data for Bangladeshi households, 3 and is a key reference for policy and development interventions for health, nutrition, food security, homestead food production, gender disparities, and rural and urban poverty.

The data collection followed a two-stage cluster sampling design. In the first stage, 628 slums were selected from 32 distinct urban slum wards in the six largest cities in Bangladesh using simple random sampling. In the second stage, households were systematically sampled within each slum in rough proportion to the number of urban slum wards in each city - that is, approximately 50 households per urban slum ward - for a total sample of 9000 households (see Appendix).

Responses were collected through face-to-face interviews with the mother in each household. Verbal consent was obtained from each respondent after explaining the purpose and scope of the data collection. The interviews were conducted by field teams composed of two data collection officers, at least one of whom was a woman. All the interviewers were trained by HKI before each round of data collection; during each round, monitoring teams from HKI visited field sites to supervise data collection. Quality control teams also recollected 5-10\% of the data on the following day. All data were entered by staff of local NGOs partners using a software package developed by HKI. Duplicate, mismatch, consistency, and range checks were conducted on the final dataset in the Dhaka office of HKI by experienced staff.

\section{Dependent Variables}

Enterprise resilience. HKI included detailed information on the self-reported occupation of the main household earner, defined for the NSP as the person who provided the majority of the household income, during the latest 2 months. Based on a systematic review of the literature on employment alternatives in Bangladesh (e.g., Choudhury \& Wahid, 1995), we constructed a dummy variable that took a value of 1 if the main household earner had a paying but non-salaried occupation (businessman, rickshaw/cart/van puller/baby taxi driver/boatman, household help, petty businessman, collection for sale). Salaried occupations (salaried worker, professional, skilled laborer, unskilled laborer, garment factory worker, factory worker, cottage industry worker, household help, agricultural day laborer) and non-paying labor (beggar, housewife, retired, unemployed, and others) received a score of 0.

Income. We operationalized income using the nutritional intake of each household on a weekly basis. HKI interviewers asked each mother about the number of times (in the past 7 days) that their household had consumed the staple dal (lentils), green leafy vegetables, yellow or orange fruits and vegetables, eggs, fish, poultry, or other meats. We aggregated these seven measures into an additive index. 


\section{Predictors and Moderators}

Gender. HKI's NSP recorded the gender of the household head as a dummy variable that took a value of 1 if the household head was female and 0 if the household head was male.

Informality. To classify entrepreneurial activities as either formal or informal we cross-referenced HKI's data on household head's main occupations against occupational ethnographies and research studies in Bangladesh (Choudhury, 2003; Choudhury \& Wahid, 1995; Islam, 1997; Opel, 2000; Saha \& Rahman, 2006a, 2006b; Salway et al., 2003). We constructed a dummy variable that took a value of 1 if the main household earner engaged in informal business activities, that is, paying but nonsalaried occupations (businessman, rickshaw/cart/van puller/baby taxi driver/boatman, household help, petty businessman, collection for sale), and 0 if they engaged in formal business activities (businessman).

Education. The HKI database recorded the number of years of education for both the mother and the father of each household. Because these two measures were highly correlated (inter-item correlation 0.56, Cronbach's alpha 0.72), we constructed a composite measure for education, adding the standardized scores of maternal and paternal education. All our results are robust to including only the level of education of the household head.

\section{Analyses}

All our models were tested using a two-stage instrumented variable approach (Stata's ivreg2). All models used robust error estimation, controlling for error commonalities due to similarities within urban slum wards (see Appendix).

First stage. The first stage of the models predicts enterprise resilience, using five different instruments: two indicators of household needs (Household size and Mother age) and three indicators of household resourcefulness (Sanitary infrastructure, Water infrastructure, and Household accommodation). Household needs vary with family size and family age (Davis, 2006). HKI provides information on the exact number of members in each household, defined as "the group of people who live together and take food from the same cooking pot" (Household size). The HKI definition includes household members living elsewhere but staying at the house for at least one night in 3 months, as well as non-family members who had lived with the household members for at least 6 months. HKI also records the age of the mother in each household (Mother age). Water and sanitary infrastructure are scarce in slum areas, and access to superior water and sanitary infrastructure offers important proxies for the household resourcefulness in overcoming local constraints (Davis, 2006). We operationalized Sanitary infrastructure using a dummy variable that took a value of 1 if the usual place of defecation for the household was a latrine (open or closed), and 0 if household members usually defecate in the bush/open field, at the river/pond side, in a drain, canal or dustbin, or other. Water infrastructure was similarly operationalized using a dummy variable, which took a value of 1 if the source of drinking water for the household was a tap or a hand-pump, and 0 if the source was rain, spring, pond, river, canal, or well water. A larger living area is another good indicator of superior household resourcefulness (Davis, 2006). Household accommodation was derived from the HKI measurements of the length and width or the main living house for each household. 
Our first-stage models also include five dummy control variables to account for different economic opportunities in the six growing seasons: February-March for spring (Bashonto), April-May for summer (Grishmo), June-July for the rainy season (Borsha), August-September for pre-autumn (Sharot), October-November for late autumn (Hemonto), and December-January for winter (Sheeth). Spring was our reference category. We also control for the level of Local unemployment, using the HKI's NSP data to infer the percentage of nonpaying labor to paying occupations across all the urban slums within each of the six cities included in the study. Sensitivity analyses confirm that our results are robust to narrower (only unemployed) or broader (including beggar, housewife, retired, and/ or others) operationalizations.

Second stage. The second stage of our instrumented variable models predicts income using the fitted values of enterprise resilience, regressed on instruments and covariates to isolate variation in enterprise resilience uncorrelated with the prediction error for income. Because using fitted values inevitably causes a loss in the efficiency of estimation (Wooldridge, 2002), we verified that the loss of efficiency is acceptable by testing whether the relevance and orthogonality conditions are fulfilled (Murray, 2006). Relevance refers to the strong fit between the endogenous regressor and the instruments used to model it. The most robust and conservative test of relevance is the firststage F-statistic, which tests the hypothesis that all the coefficients of the instruments used equal 0; significant F-statistics that exceed the threshold of 9.08 for three instruments, and 10.83 for five instruments, reflect strong instruments that satisfy the relevance condition (Stock \& Yogo, 2004). The orthogonality condition verifies that the instruments are not correlated with the error term, that is, that at least one instrument is exogenous (Wooldridge, 2006). Violation of the orthogonality condition causes inconsistent estimation (Bascle, 2008). We used the Hansen J-statistic to test this assumption, because our error terms are heteroscedastic; a failure to reject this statistic (i.e., a nonsignificant Hansen J) offers assurance that the instruments can be considered exogenous. All our models met the relevance and orthogonality conditions. All F-statistics were significant at $\mathrm{p}<0.001$; they ranged from 13.5 to 24.09 for the cross-group analyses, and 5.96 to 17.11 in the subgroup post-hoc analyses. All Hansen J-statistics were non-significant.

Causality. The decision on whether or not one should engage in enterprise activities may depend on gender (Smith-Hunter, 2006), formal vs informal sector opportunities (Webb et al., 2009), education (SEEP, 2007), and on the levels and conditions of terrorism (Wenger \& Möckli, 2003). Our two-stage instrumented regression models account for the possibility of reverse causality, for example, that greater frequency, intensity and scope of terrorism or informality and education barriers influence enterprise resilience. All first-stage models estimate the effects of the level of terrorism following each terrorism condition and the effects of gender, informality and education on enterprise resilience. Controls for the effects of the covariates, that is, Local unemployment and the (unreported) effects of the five growing season dummy variables, are also included in all our models in the first stage.

Common method variance. We rely on independent sources of primary and secondary data to mitigate concerns of common method variance. The operationalizations of the conditions (Hypothesis 1) and levels of terrorism (Hypotheses 4 and 5) rely on secondary data, triangulated against multiple reports of terrorist events. Both gender (Hypothesis 2) and enterprise resilience (Hypothesis 3) are based on self-reports collected by research teams (and in some cases verified by supervisory teams). Confidence in the proposed direction of causality is reinforced by the 1-year time lag between our first-stage criterion (enterprise resilience) and predictors (terrorism 
conditions), and between our second-stage criterion (income) and moderator (level of terrorism). Enterprise resilience and income are collected using the same instrument at the same point in time. However, enterprise resilience is instrumented using self-reports of observable variables, some validated by the data collection teams in the field (e.g., Household accommodation). Informality and education are also collected using the same instrument and at the same point in time as income. However, our operationalization of informality independently classifies the self-reported descriptions of occupations as either formal or informal, relying on studies that analyze economic activities in Bangladesh. We use cumulative measures of education, which necessarily precede the observed occupation and income.

\section{RESULTS}

The sample descriptive and zero-order correlations are shown in Table 1. Enterprise resilience and income are positively associated $(0.032, \mathrm{p}<0.05)$. Informality and income are negatively associated when we partial out the level of terrorism $(-0.157, \mathrm{p}<0.05)$, indicating an informality penalty. Education and income are positively correlated when we partial out the level of terrorism $(0.272$, $\mathrm{p}<0.05$ ), confirming an education premium. Contrasts between these partial correlations and the zero-order correlations reported in Table 1 offer preliminary support for the predicted moderation effects.

Table 1 also supports our instrumentation: enterprise resilience is driven by household needs; heads of larger and younger households are also more likely to engage in enterprise activities (Household size, 0.049, $\mathrm{p}<0.05$; Mother age, $-0.025, \mathrm{p}<0.05$ ). The 9000 households surveyed averaged about 5 members, ranging from 2 to 19 members. In our sample, mothers were on average 25 years old, with a wide age distribution from 13 to 60. Living conditions were modest. Although the vast majority of the interviewed households had access to an open or closed latrine, and three quarters had access to tap or hand-pump sourced water, the average dwelling was only $158 \mathrm{ft} 2(14.7 \mathrm{~m} 2)$.

\section{Insert Table 1 About Here}

Table 2 provides additional support for our instrumentation. Household size and Household accommodation are robust predictors of enterprise resilience. Mother age has a negative effect: net of constraints and resources, younger mothers are marginally more likely than older mothers to engage in enterprise activity. Sanitary infrastructure also has a marginal beneficial effect. All the models meet the relevance and the orthogonality conditions ( $F=35, \mathrm{p}<0.001$; Hansen Jstatistic=9.837, $\mathrm{p}=0.079$ ). 


\section{Insert Table 2 About Here}

\section{Terrorism Conditions}

In our sample of 9000 households living in urban slums in the six largest municipalities in Bangladesh, we observe the highest enterprise resilience in the terrorism escalation condition (mean 0.495, s.d. 0.500), followed by terrorism absence (mean 0.485, s.d. 0.499), terrorism outbreak (mean 0.471, s.d. 0.499) and terrorism reduction (mean 0.445, s.d. 0.497). Although Bonferroni contrasts show no statistically significant differences among consecutive means, between conditions differences are significant $(F=4.15, p<0.01)$. Specifically, enterprise resilience is significantly higher in the terrorism escalation condition than in the terrorism reduction condition $(\mathrm{p}<0.01)$, and enterprise resilience is marginally lower in the terrorism reduction condition than in the absence of terrorism $(\mathrm{p}<0.10)$. The changes in the number of enterprises between terrorism conditions (a 5\% difference between escalation and reduction; a 4\% gap between reduction and absence) are also practically meaningful.

Our models test the effects of the natural experiment conditions simultaneously; terrorism absence is our reference category. The reported effects are fully replicated when testing each condition separately. Model 1 in Table 2 reports the effect of terrorism outbreak, escalation and reduction conditions (i.e., the change from the first 2-year window to the second 2-year window) without accounting for the level of terrorism most recently experienced by the respondents (i.e., a composite indicator of the intensity, frequency, and scope of terrorism; Ross, 1993). However, the level of terrorism may influence enterprise resilience. Higher levels of terrorism increase perceived risk. Because returns to enterprise activities should increase at least roughly proportionally to perceived risk, we expect a positive association between enterprise resilience and income. Model 2 in Table 2 confirms this expectation. The level of terrorism explains $10 \%$ additional variance in income. Both the significance and the magnitude of the effects are robust to the inclusion or exclusion of the covariates and the interaction effects. Because the decision on whether or not one should engage in enterprise activities may depend on the conditions and levels of terrorism (Smith, 2008; Wenger \& Möckli, 2003), our two-stage instrumented regression models control for mutual causality by testing how the level of terrorism may affect enterprise resilience in the first place. Model 2 shows a counterintuitive effect. The level of terrorism has a positive effect on enterprise resilience. Greater incidence and persistence of enterprise activities at higher than lower levels of terrorism, controlling for terrorism conditions, lend support to prior anecdotes and arguments that enterprise activities can flourish under extreme adversity.

The positive effect of the terrorism outbreak condition on enterprise resilience $(0.331, p<0.05$, Model 1, Table 2) is suppressed by the positive effect of the level of terrorism following the outbreak (-0.718, $<<00.10$, Model 2, Table 2). Controlling for the level of terrorism following the increase in conflict, the terrorism outbreak condition has a negative effect on enterprise resilience. Hypothesis 1a is not supported.

The terrorism escalation condition also has a negative effect on enterprise resilience when we account for the level of terrorism following the escalation $(-1.764, \mathrm{p}<0.05$, Model 2, Table 2$)$, and no effect otherwise (-0.001, n.s., Model 1, Table 2). Hypothesis $1 \mathrm{~b}$ is not supported. 
These non-findings are noteworthy, because they split the paradoxical observation of greater enterprise resilience under extreme adversity into two separate arguments. On one hand, worsening terrorism hinders enterprise resilience, and terrorism escalation hinders enterprise resilience more than terrorism outbreak. On the other hand, the level of terrorism following either a small or a large aggravation has a counterintuitive, positive effect on enterprise resilience, perhaps because higher levels of terrorism increase the economic payoffs to enterprise activities relative to alternative livelihoods.

As predicted, the terrorism reduction condition has a positive effect on enterprise resilience 0.343 , $\mathrm{p}<0.05$, Model 2, Table 2), robust to the level of terrorism following the reduction $(0.493, \mathrm{p}<0.05$, Model 2, Table 2). Hypothesis $1 \mathrm{c}$ is borne out by the data. This finding provides empirical support for one of the stronger-held working assumptions of peace-through-commerce interventions - that post-conflict, war-torn communities have a strong incentive to (re)engage in enterprise activities and rebuild livelihoods (Lederach, 2008). We also show that terrorism reduction has a robust positive effect on enterprise resilience, even when the level of terrorism following the reduction remains high.

\section{Gender}

Hypothesis 2 predicts greater enterprise resilience for women than for men in the terrorism outbreak (Hypothesis 2a), escalation (Hypothesis 2b), and reduction (Hypothesis 2c) conditions. Model 3 in Table 2 reports the simultaneous effects of the three gender moderation effects on the instrumented dependent variable for our first-stage model, enterprise resilience. Examining each moderation effect separately fully replicates the reported results. None of the predicted gender moderations is borne out by the data: enterprise resilience is not significantly different between women and men. Post-hoc probing within each terrorism condition reported in Table 3 shows a non-significant main effect of gender on enterprise resilience in the terrorism outbreak condition. Furthermore, the percentage of women entrepreneurs was similar in the terrorism outbreak $(4.9 \%)$ and the terrorism absence $(4.7 \%)$ conditions. Taken together, these results triangulate the non-significant moderation reported in Model 3, Table 2. Hypothesis 2a is not supported. Post-hoc probing reported in Table 3 further shows that gender has a negative effect on enterprise resilience, that is, enterprise resilience is lower for women than men, for both the terrorism escalation and the terrorism reduction conditions. The prevalence of women entrepreneurs was three times lower in the terrorism escalation condition $(2.3 \%)$ than in the terrorism reduction condition (6.3\%). These observations confirm the negative main effect of gender reported in Table 2 , and provide further insight into the non-significant results for Hypothesis $2 \mathrm{~b}$ and Hypothesis 2c.

The absence of gender moderation for enterprise resilience under terrorism is noteworthy. Not only do our findings challenge prior qualitative evidence that women may be more likely to step into entrepreneurial roles under extreme adversity (Abdelnour \& Branzei, 2009b; Ayadurai \& Sohail, 2006; El Jack, 2007), but they also provide a systematic comparison of the base rates of women and men entrepreneurs across different terrorism conditions. Our design may underestimate the incidence of women-led enterprise (i.e., women may engage in enterprise activities when the male household head is also an entrepreneur). Yet the contrast is stark: women entrepreneurs headed only one in 25 of the 9000 households surveyed. When terrorism escalated, women entrepreneurs headed only one in 50 households. 


\section{Enterprise Resilience}

Enterprise resilience has a positive effect on income. Hypothesis 3 receives strong support (Model 3 , Table 2). Table 3 further shows that returns to enterprise resilience are significant within each terrorism condition, and higher in magnitude in environments with recurrent conflict (terrorism reduction and outbreak) than in environments without prior terrorism (terrorism absence and terrorism outbreak). The positive effect of enterprise resilience on income is robust to the inclusion of the hypothesized two-way interaction effects between informality, respectively education, and the level of conflict (Models 4-5, Table 2). It is also robust to the inclusion of the (nonsignificant) three-way interaction effect (Models 6-7, Table 2). OLS robustness checks show that adding enterprise resilience to a regression model explains $1.3 \%$ additional variance in income after controlling for the level of terrorism, informality and education.

\section{Insert Table 3 About Here}

\section{The Informality Penalty}

In our instrumented variable regressions (Model 4, Table 2), informality has a consistent negative main effect on income. This empirical result corroborates earlier predictions that informal entrepreneurs earn less than formal entrepreneurs in the developingcountry settings in general (de Soto, 1989), and urban slums more specifically (Davis, 2006). Hypothesis 4 explains why the negative effect of informality on income may be weaker at higher levels of terrorism. The interaction term is significant, adding $2 \%$ explained variance, and positive, confirming our expectation that the penalty to informality may be lower at higher levels of terrorism. The results account for the possibility of mutual causation, controlling for any beneficial effects of informality on enterprise resilience in the first-stage models. In OLS robustness checks, informality explains $2.5 \%$ additional variance in income after controlling for local unemployment and the growing season, and 1\% after controlling for education. Figure 2 presents the post-hoc moderation probing. As hypothesized, the slope is negative and flatter at higher levels of terrorism.

The interaction effect between informality and the level of terrorism predicted by Hypothesis 4 is borne out by the data. This finding complements recent theorizing about the returns to informality by suggesting that the penalty to informality may be context-contingent. We show that the expected gap between formal and informal entrepreneurs narrows at higher levels of terrorism. Informality may not only become an economically rational choice under extreme adversity and/or conflict; it may also fulfill a temporary emancipation rather than a persistent entrapment function. By explicating the contextual contingencies to the informality penalty, models of entrepreneurship in developing countries can theorize informality as a viable transitional stage (Webb et al., 2009).

Insert Figure 2 About Here 


\section{The Education Premium}

In our instrumented variable models, education has a consistent positive main effect on income, corroborating prior evidence of an education premium: better education yields higher payoffs to enterprise activities across a wide variety of contexts and occupations (Honig, 2001; Lerner et al., 1997; Manolova et al., 2007). In OLS regression, education explains 5.2\% additional variance in income after controlling for local unemployment and growing season, and 3.7\% after controlling for informality.

Hypothesis 5 explains why the positive effect of education on income may be weaker at higher levels of terrorism. Model 5 in Table 2 reports a non-significant interaction between education and the level of terrorism. Post-hoc moderation probing in Figure 2 shows the expected positive slope, which does flatten - but only slightly - at higher levels of terrorism. Education yields similar positive payoffs as the level of terrorism increases. Hypothesis 5 is not supported.

Because less-educated entrepreneurs are more likely to operate in the informal sector, they may incur the dual penalty of informality and lack of education (Azevedo, 2005; Mead \& Morrisson, 1996). The three-way interaction among informality, education, and the level of terrorism was nonsignificant (Models 6 and 7, Table 2). Table 3 confirms the dual penalty in the terrorism absence condition; informality and education have independent direct and terrorism-contingent effects in all the other terrorism conditions.

\section{DISCUSSION}

This study begins to flesh out a missing but important facet of entrepreneurship in developing countries, by explaining the causes and consequences of enterprise resilience within and across terrorism settings. We build closely on prior insights into the antecedents and consequences of international entrepreneurship in small family business (Casillas et al., 2007), women entrepreneurship in the global marketplace (Salway et al., 2003; Sethuraman, 1998; Smith-Hunter, 2006), and informal entrepreneurship (Bacchetta et al., 2009; Webb et al., 2009). Our propositions and findings begin to fill in the (still) missing link between the role that business might play in unstable and postconflict settings and the economic motivation for entrepreneurship in BOP settings. We suggest that entrepreneurship can provide a two-step transition from the disruption caused by terrorism, and explore when and why urban slum dwellers in developing countries (re)engage in economic activities in the aftermath of terrorism. We also seek to draw greater attention to how, why and when urban slum dwellers take on entrepreneurial roles in lowerincome markets in developing countries, despite deep poverty and scarcity (London, 2009), systematic barriers (SEEP, 2007), and pervasive constraints (Yunus, 1998).

\section{Theoretical Contributions}

Our study makes a distinctive contribution to international business (Tung \& van Witteloostuijn, 2008) by beginning to articulate the psychological and economic rationale for (re)engagement in enterprise activities in the direst of circumstances. The straightforward claim that enterprise can emancipate the poor is not new (Davis, 2006; de Soto, 1989, 2000). Development economists have long argued that (re)engagement in economic activities helps restore the social fabric in which 
economic exchanges can flourish (Nelson, 2000). Recent research reaffirms this belief in peaceful contexts (Branzei \& Peneycad, 2008) and postconflict settings (Abdelnour \& Branzei, 2009a). Nor is evidence of enterprise resilience in times of conflict (Ayadurai \& Sohail, 2006; El Jack, 2007). Several studies note a greater incidence or persistence of entrepreneurship in contexts torn by sudden or recurrent terrorism (e.g., Ireland, US, UK, Spain, India, Yemen, Sri Lanka, and Iraq). However, our theoretical and empirical focus on entrepreneurship under adversity is firmly anchored in the entrepreneurship literature, and extends this literature in three important ways.

First, it draws poignant attention to a large and growing population of entrepreneurs, who have been so far only sporadically addressed in both the peace-through-commerce and the BOP literatures, despite their critical role in social and economic value creation. Although these entrepreneurs are not typically involved in transactions that cross national boundaries, they bear the brunt of globalization - especially its unintended consequences (Bacchetta et al., 2009; Griffith et al., 2008; Opel, 2000). They often represent important participants in global value chains (Lodge \& Wilson, 2006; Wilson \& Wilson, 2006; World Bank, 2007) and may help (re)structure economic exchanges in subsistence markets (Abdelnour \& Branzei, 2009a; Azim, 2008; Fadahunsi \& Rosa, 2002).

Second, we argue that some of the most wellaccepted premises of entrepreneurship need to be carefully rethought and retested in post-conflict settings. Our hypotheses reaffirm the oftenmentioned barriers to women (Smith-Hunter, 2006), the penalty to informality (Webb et al., 2009), and the education premium (Yunus, 1998). But we also explain why these barriers may be less pervasive or oppressive in the aftermath of terrorism. In our single-country tests, controlling for the conditions and the level of terrorism, gender does not moderate the propensity to take on entrepreneurial roles in each terrorism condition. The payoff gap between formal and informal enterprise narrows at higher levels of terrorism. The education premium also decreases, but only slightly.

Third, we provide a more nuanced understanding of the role of business in post-conflict settings (Wenger \& Möckli, 2003) by discussing the recursive relationship between terrorism and enterprise resilience. We specifically unpack the pro-peace functions of enterprise by showing that the (in)ability of enterprise resilience to mitigate disruption and destruction is dually contingent on both the conditions and the level of terrorism. Our findings confirm the intuitive expectation that a reduction in terrorism is most likely to encourage enterprise activities, and that returns to enterprise resilience are higher in this condition, especially for informal entrepreneurs. This insight dovetails with recent arguments that informal entrepreneurship may represent a transitional stage (Webb et al., 2009), deserving of attention and support - especially during post-conflict stabilization and reconstruction. Our findings further show that terrorism escalation discourages entrepreneurship. Only a few may grow into entrepreneurial roles in the face of adversity; most fall back on other means to provide for their families. For the few, however, economic motivators are particularly strong under recurrent disruption: heightened risk yields higher returns to enterprise resilience in the terrorism escalation condition. In our study, terrorism outbreak is the most paralyzing to enterprise activities: it both stalls (re)engagement and provides the least economic motivation (i.e., returns to enterprise resilience are lower under terrorism outbreak than in all other cases). 


\section{Limitations and Future Research}

Although our cross-sectional research design cannot directly examine the evolution of enterprise resilience as terrorism unfolds, the systematic contrast across conditions of terrorism may offer a promising starting point for future studies on conflict life cycles. Taking one step beyond our empirical findings, the pattern of results has enterprise resilience decrease from the pre-violence to the violence stage and increase from the violence to the post-violence stage. This suggests a possible U-shape relationship between the conflict life cycle and enterprise resilience (Wenger \& Möckli, 2003: 32). Understanding how the incidence of and returns to enterprise activities change across the conflict life cycle can extend the peace-throughcommerce research to more openly address the propeace functions of enterprise and the interface between enterprises and other actors, including MNEs.

The poor and marginalized in developing countries respond to changes in terrorism conditions and levels in ways that may systematically pattern value creation and market exchanges. Explicating the relationship between enterprise resilience and terrorism complements growing interest in the roles of transnational corporations in conflict prevention (Wenger \& Möckli, 2003) and postconflict stabilization (Williams, 2008). Although it is too early to predict whether or how enterprise resilience enables or hinders MNE engagement, we encourage peace-through-commerce to more systematically address the interface between small and large firms, and especially between formal and informal ventures. We need to move beyond the simple question of whether MNEs should engage, to where and when MNEs can work together with small and local entrepreneurs to stabilize markets, forge new exchange relationships, and reconfigure value chains to create both social and economic value.

A secondary theoretical implication of our study concerns the applicability of our findings to other types of conflict (Jacoby, 2008) - that is, in the aftermath of sudden or recurrent crisis (e.g., earthquakes, tsunamis, Tang, 2006), structural upheaval (Honig, 2001), displacement (El Jack, 2007) or prolonged combat (Abdelnour \& Branzei, 2009b). Our findings speak directly to specific economic effects of terrorism in urban slums in Bangladesh. Generalizations to other national, institutional, and cultural settings affected by terrorist events (in South Asia, Kumaraswamy, 2007; or globally, Smith, 2008) should proceed with caution. Our theory and findings may not apply to other forms of violence such as ethnic or armed conflict (Oberschall, 2007), or other forms of socioeconomic disruptions, such as repressive regimes and/or systematic market distortions (Cross \& Morales, 2007).

A third extension concerns the methodology used to grapple with the dynamic nature of enterprise resilience across different types and trends of conflict. Mixed method designs can provide complementary strengths. For example, action research that tracks the specific goals and consequences of enterprise interventions postconflict (Abdelnour \& Branzei, 2009b) can be complemented with entrepreneurs' evolving lifenarratives to track how their perceptions, attributions, and motivations may change in response to conflict life cycles. Large-scale surveys that explore the longitudinal or multilevel effects of conflict can be supplemented by experiments conducted in naturalistic settings to shed light on the specific mechanisms underpinning the observed trends or effects. 


\section{Practical Implications}

Our findings advance prior debates on whether enterprise-focused interventions are worthwhile in the aftermath of conflict (Nelson, 2000), to how and when such interventions can yield greater social and/or economic value. Enterprise resilience plays an important role in promoting sustainable peace (Fort \& Schipani, 2004) and creating social and economic value (Simanis et al., 2008). Although the pro-peace functions of enterprise are deemed increasingly important in restoring socioeconomic stability (SEEP, 2007), and the beneficial effects of enterprise activities are supported by ethnographic observations in post-conflict settings (e.g., in Sudan, Abdelnour \& Branzei, 2009b; in South Africa, Aymes, 1989), there are hardly any rigorous studies of enterprise resilience at, and across, different levels of conflict. Our study holds several key implications for post-conflict interventions targeting enterprise development.

Because enterprise resilience is simultaneously influenced by the conditions and the level of conflict, we recommend that international development interventions take both into account in deciding which settings and/or at what times may benefit the most. Our findings in Bangladesh suggest that development efforts may be best channeled towards settings that have experienced a reduction in terrorism, especially if the level of terrorism following the change remains high - a combination of conditions that may provide the highest returns to enterprise activities. We also suggest that interventions may be least effective when terrorism escalates suddenly, especially if the level of terrorism following the escalation remains high. Last, we reconcile prior successes and failures under persistent adversity. When terrorism is recurrent, returns to enterprise activities are high, but very few are willing or able to bear the risk. We can extrapolate our findings to speculate that it may be much harder to "turn around" a context after a sudden outbreak than to stabilize a context that has experienced a reduction in the level of terrorism. Taking another (speculative) step beyond the empirical setting of our research, interventions may be more likely to succeed when they work with, rather than against, the life cycle of conflict.

\section{CONCLUSION}

This study extends the literature of international entrepreneurship by explaining how, why, and when the urban poor in developing countries may emerge as entrepreneurs in the aftermath of terrorism. We develop both psychological and economic explanations for the counterintuitive observation that enterprise may flourish under extreme adversity and conflict. We model the returns to enterprise activities at different conditions and levels of terrorism, and suggest how taking both into account can increase the odds of success for international development interventions in post conflict settings. 


\section{NOTES}

1BRAC was initially called the Bangladesh Rehabilitation Assistance Committee.

${ }^{2}$ According to the 2001 Population Census, Bangladesh Bureau of Statistics, Statistics Bangladesh 2006, http://www.bbs.gov.bd/dataindex/stat_bangladesh .pdf. Accessed 7 July 2009.

${ }^{3} \mathrm{~A}$ household was eligible for inclusion in the NSP if it contained at least one physically able child under 5 years of age, and if the mother was present. 


\section{REFERENCES}

Abdelnour, S., \& Branzei, O. 2009a. Fuel-efficient stoves for Darfur: The social construction of subsistence marketplaces in post-conflict settings. Journal of Business Research, Advance online publication, 14 July. doi:10.1016/j.jbusres.2009.04.027.

Abdelnour, S., \& Branzei, O. 2009b. The renaissance of community enterprise in postwar Sudan. In S. Carayannopoulos (Ed.) Proceedings of the Administrative Science Association of Canada, 6-9 June. Niagara Falls, Canada: Sobey School of Business of St. Mary's University.

Aidis, R., \& van Praag, M. 2007. Illegal entrepreneurship experience: Does it make a difference for business performance and motivation? Journal of Business Venturing, 22 (2): 283-310.

Ayadurai, S., \& Sohail, M. S. 2006. Profile of women entrepreneurs in a war-torn area: Case study of North East Sri Lanka. Journal of Developmental Entrepreneurship, 11 (1): 3-17.

Aymes, G. W. 1989. The Spaza Shop growth phenomenon: Is it real? Marketing Mix, 7 (6): 14.

Azevedo, J. P. 2005. An investigation of the labour market earnings in deprived areas: A test of labour market segmentation in the slums. Anais do XXXIII Encontro Nacional de Economia, ANPEC - Associação Nacional dos Centros de Pósgraduação em Economia. http://www.anpec.org.br/encontro2005/artigos/A05A162.pdf. Accessed 7 February 2008.

Azim, M. T. 2008. Socio-cultural environment for entrepreneurship development in Bangladesh. Journal of Bangladesh Studies, 10 (1): 51-60.

Bacchetta, M., Ernst, E., \& Bustamante, J. P. 2009. Globalization and informal jobs in developing countries: A joint study of the International Labour Office and the Secretariat of the World Trade Organization. Geneva: WTO Secretariat.

Baron, R. A., \& Markman, G. D. 2000. Beyond social capital: How social skills can enhance entrepreneurs' success. Academy of Management Executive, 14 (1): 106-116.

Bascle, G. 2008. Controlling for endogeneity with instrumental variables in strategic management research. Strategic Organization, 6 (3): 285-327.

Blomberg, S. B., Hess, G. D., \& Orphanides, A. 2004. The macroeconomic consequences of terrorism. Journal of Monetary Economics, 51 (5): 1007-1032.

Bonanno, G. A., Galea, S., Bucciarelli, A., \& Vlahov, D. 2007. What predicts psychological resilience after disaster? The role of demographics, resources, and life stress. Journal of Consulting and Clinical Psychology, 75 (5): 671-682.

Branzei, O., \& Peneycad, M. 2008. Weaving sustainable partnerships in Zanzibar: The social fabric of women entrepreneurship. In R. Hamann (Ed.) The business of sustainable development in Africa: Human rights, partnerships, and new business models: 192-210. Pretoria: Unisa Press.

Calás, M. B., Smircich, L., \& Bourne, K. A. 2009. Extending the boundaries: Reframing "entrepreneurship as social change" through feminist perspectives. Academy of Management Review, 34 (3): 552-569. 
Carter, M. R., \& Maluccio, J. A. 2003. Social capital and coping with economic shocks: An analysis of stunting of South African children. World Development, 31 (7): 1147-1163.

Casillas, J. C., Acedo, F. J., \& Moreno, A. M. 2007. International entrepreneurship in family business. Cheltenham: Edward Elgar.

Choudhury, M. A., \& Wahid, A. N. M. 1995. Social frictions and social dynamics: Their impact on the development process. In A. N. M. Wahid (Ed.) The economy of Bangladesh: Problems and prospects: 17-32. Westport, CT: Greenwood Publishing Group.

Chowdhury, M. H. 2003. Violence, politics and the state in Bangladesh. Conflict, Security and Development, 3 (2): 265-276.

Choudhury, M. S. 2003. Poorest women in Bangladesh: Economic paths to socio-political development. Journal of Bangladesh Studies, 5 (2): 30-41.

Cross, J., \& Morales, A. 2007. Street entrepreneurs: People, place and politics in local and global perspective. New York: Routledge.

Davis, M. 2006. Planet of slums. London: Verso.

de Bruin, A., Brush, C., \& Welter, F. 2007. Advancing a framework for coherent research on women's entrepreneurship. Entrepreneurship Theory and Practice, 31 (3): 323-339.

del Ninno, C., Dorosh, P. A., \& Smith, L. C. 2003. Public policy, markets and household coping strategies in Bangladesh: Avoiding a food security crisis following the 1998 floods. World Development, 31 (7): 1221-1238.

de Soto, H. 1989. The other path: The invisible revolution in the third world. New York: Harper \& Row.

de Soto, H. 2000. The mystery of capital: Why capitalism triumphs in the West and fails everywhere else. New York: Basic Books.

El Jack, A. 2007. Gendered implications: Development-induced displacement in Sudan. In P. Vandergeest, P. Idahosa, \& P. S. Bose (Eds) Development's displacements: Ecologies, economies, and cultures at risk: 61-81. Vancouver: UBC Press.

Fadahunsi, A., \& Rosa, P. 2002. Entrepreneurship and illegality: Insights from the Nigerian crossborder trade. Journal of Business Venturing, 17 (5): 397-429.

Fort, T. L., \& Schipani, C. A. 2004. The role of business in fostering peaceful societies. Cambridge: Cambridge University Press.

Fredrickson, B. L. 2006. The broaden-and-build theory of positive emotions. In M. Csikszentmihalyi \& I. S. Csikszentmihalyi (Eds) A life worth living: Contributions to positive psychology, Series in Positive Psychology. 85-103. Oxford: Oxford University Press.

Fredrickson, B. L., Tugade, M. M., Waugh, C. E., \& Larkin, G. 2003. What good are positive emotions in crises? A prospective study of resilience and emotions following the terrorist 
attacks on the United States on September 11th, 2001. Journal of Personality and Social Psychology, 84 (2): 365-376.

Garlan, R. W., Butler, L. D., \& Spiegel, D. 2005. Psychosocial resilience and terrorism. Directions in Psychiatry, 25: 151-163.

Gerson, A., \& Colletta, N. J. 2002. Privatizing peace: From conflict to security. Ardsley, NJ: Transnational Publishers.

Goodhand, J., \& Hulme, D. 1999. From wars to complex political emergencies: Understanding conflict and peace-building in the new world disorder. Third World Quarterly, 20 (1): 13-26.

Griffith, D. A., Cavusgil, S. T., \& Xu, S. 2008. Emerging themes in international business research. Journal of International Business Studies, 36 (7): 1220-1235.

Hammond, A. L., Kramer, W. J., Robert, S. K., Tran, T., \& Walker, C. 2007. The next 4 billion, market size and business strategy at the base of the pyramid, World Resources Institute International Finance Corporation. http://pdf.wri.org/n4b fulltext hi.pdf. Accessed 15 September 2009.

Hmieleski, K. M., \& Carr, J. C. 2007. The relationship between entrepreneur psychological capital and well-being. In A. Zacharakis, S. Alvarez, M. S. Cardon, J. O. de Castro, G. George, D. F. Kuratko, M. Maula, M. Minniti, S. D. Sarasvathy, D. A. Shepherd, P. Westhead, J. Wiklund, M. Wright, \& S. A. Zahra (Eds.) Frontiers of entrepreneurship research. http://www.babson.edu/entrep/fer/2007FER/default.htm. Babson Park, MA: Babson College.

Honig, B. 1998. What determines success? Examining the human, financial, and social capital of Jamaican microentrepreneurs. Journal of Business Venturing, 13 (5): 371-394.

Honig, B. 2001. Human capital and structural upheaval: A study of manufacturing firms in the West Bank. Journal of Business Venturing, 16 (6): 575-594.

Islam, N. 1997. Addressing the urban poverty agenda in Bangladesh. Dhaka: University Press Limited.

Jacoby, T. 2008. Understanding conflict and violence: Theoretical and interdisciplinary approaches. London: Routledge.

Joseph, S., \& Linley, P. A. 2008. Trauma, recovery, and growth: Positive psychological perspectives on posttraumatic stress. Hoboken, NJ: Wiley.

Karnani, A. 2007. The mirage of marketing to the bottom of the pyramid: How the private sector can help alleviate poverty. California Management Review, 49 (4): 90-111.

Kumaraswamy, P. R. 2007. Terrorism in South Asia: The changing trends. South Asia: Journal of South Asian Studies, 30 (1): 7-24.

Langowitz, N., \& Minniti, M. 2007. The entrepreneurial propensity of women. Entrepreneurship Theory and Practice, 31 (3): 341-364. 
Lederach, J. P. 2003. The little book of conflict transformation. Intercourse, PA: Good Press.

Lederach, J. P. 2008. The role of corporate actors in peace-building processes: Opportunities and challenges. In O. F. Williams (Ed.) Peace through commerce: Responsible corporate citizenship and the ideals of the United Nations Global Compact: 96-106. South Bend, IN: University of Notre Dame Press.

Lerner, M., Brush, C., \& Hisrich, R. 1997. Israeli women entrepreneurs: An examination of factors affecting performance. Journal of Business Venturing, 12 (4): 315-339.

Lindner, E. 2009. Emotion and conflict: How human rights can dignify emotion and help us wage good conflict. Westport, CT: Praeger.

Linley, P. A., \& Joseph, S. 2004. Positive change following trauma and adversity: A review. Journal of Traumatic Stress, 17 (1): 11-21.

Lodge, G., \& Wilson, C. 2006. A corporate solution to global poverty: How multinationals can help the poor and invigorate their own legitimacy. Princeton, NJ: Princeton University Press.

London, T. 2009. Making better investments at the base of the pyramid. Harvard Business Review, 87 (5): 106-113.

Lumpkin, G. T., \& Dess, G. G. 1996. Clarifying the entrepreneurial orientation construct and linking it to performance. Academy of Management Review, 21 (1): 135-172.

MacSweeney, N., \& Tanburn, J. 2008. Private sector development in post-conflict countries: A review of current literature and practice. Cambridge: DCED.

Mahajan, V., \& Banga, K. 2006. The 86\% solution: How to succeed in the biggest market opportunity of the next 50 years. Upper Saddle River, NJ: Wharton Business School Publishing.

Maitlis, S. 2009. Who am I now? Sensemaking and identity in posttraumatic growth. In L. M. Roberts \& J. E. Dutton (Eds) Exploring positive identities and organizations: Building a theoretical and research foundation: 47-76. New York: Psychology Press.

Manolova, T. S., Carter, N. M., Manev, I. M., \& Gyoshev, B. S. 2007. The differential effect of men and women entrepreneurs' human capital and networking on growth expectancies in Bulgaria. Entrepreneurship Theory and Practice, 31 (3): 407-426.

Markman, G. D., Baron, R. A., \& Balkin, D. B. 2005. Are perseverance and self-efficacy costless? Assessing entrepreneurs' regretful thinking. Journal of Organizational Behavior, 26 (1): 1-19.

McDougall, P. P., Shane, S., \& Oviatt, B. M. 1994. Explaining the formation of international new ventures: The limits of theories from international business research. Journal of Business Venturing, 9 (6): 467-487.

Mead, D. C., \& Morrisson, C. 1996. The informal sector elephant. World Development, 24 (10): 1611-1619. 
Morland, L. A., Butler, L. D., \& Leskin, G. A. 2008. Resilience and thriving in a time of terrorism. In S. Joseph \& P. A. Linley (Eds) Trauma, recovery, and growth: Positive psychological perspectives on posttraumatic stress: 39-61. Hoboken, NJ: Wiley.

Murray, M. P. 2006. Avoiding invalid instruments and coping with weak instruments. Journal of Economic Perspectives, 20 (4): 111-132.

Nelson, J. 2000. The business of peace: the private sector as a partner in conflict prevention and resolution, The Prince of Wales Business Leaders Forum, Council on Economic

Priorities. http://www.iblf.org/docs/BusinessofPeace.pdf. . Accessed 7 February 2008.

Oberschall, A. 2007. Conflict and peace building in divided societies. Routledge: New York.

Opel, A. E. A. 2000. The social content of labour markets in Dhaka slums. Journal for

International Development, 12 (5): 735-750.

Oviatt, B. M., \& McDougall, P. P. 2005. Defining international entrepreneurship and modelling the speed of internationalization. Entrepreneurship Theory \& Practice, 29 (5): 537-553.

Peredo, A. M., \& Chrisman, J. J. 2006. Toward a theory of community-based enterprise. Academy of Management Review, 31 (2): 309-328.

Prahalad, C. K. 2004. The fortune at the bottom of the pyramid: Eradicating poverty through profits. Upper Saddle River, NJ: Wharton School Publishing.

Rangan, V. K., Quelch, J. A., Herrero, G., \& Barton, B. 2007. Business solutions for the global poor: Creating social and economic value. San Francisco, CA: Jossey-Bass.

Richardson, G. E. 2002. The metatheory of resilience and resiliency. Journal of Clinical Psychology, 58 (3): 307-321.

Rindova, V., Barry, D., \& Ketchen Jr., D. J. 2009. Entrepreneuring as emancipation. Academy of Management Review, 34 (3): 477-491.

Ross, J. I. 1993. Structural causes of oppositional political terrorism: Towards a causal model. Journal of Peace Research, 30 (3): 317-329.

Saha, S. R., \& Rahman, H. 2006a. Understanding urban livelihoods in a secondary town in Bangladesh. In L. Stevens, S. Coupe, \& D. Mitlin (Eds) Confronting the crisis in urban poverty: Making integrated approaches work: 209-224. Warwickshire: Intermediate Technology Publications.

Saha, S. R., \& Rahman, H. 2006b. Understanding urban livelihoods in a secondary town: The case of Faridpur, bangladesh. http://www.research4development.info/SearchResearchDatabase.asp?OutputID=170042. Accessed 15 September 2009.

Salway, S., Rahman, S., \& Jesmin, S. 2003. A profile of women's work participation among the urban poor of Dhaka. World Development, 31 (5): 881-901. 
Seelos, C., \& Mair, J. 2007. Profitable business models and market creation in the context of deep poverty: A strategic view. Academy of Management Perspectives, 21 (4): 49-63.

SEEP. 2007. Market development in crisis-affected environments: Emerging lessons for achieving pro-poor economic reconstruction, Washington:

SEEP. http://www.seepnetwork.org/content/library/detail/5659. Accessed 7 October 2008.

Sethuraman, S. V. 1998. Gender, informality and poverty: A global review. Washington, DC: The World Bank.

Shehabuddin, E. 2004. "Development" revisited: A critical analysis of the status of women in Bangladesh. Journal of Bangladesh Studies, 6 (1): 1-19.

Simanis, E., Hart, S., DeKoszmovszky, J., Donohue, P., Duke, D., Enk, G., Gordon, M., \& Thieme, T. 2008. The base of the pyramid protocol: Toward next generation BoP strategy, Cornell University. http://www.baseofthepyramid.nl/BoPProtocol2008.pdf. Accessed 15 September 2009.

Skoufias, E. 2003. Economic crises and natural disasters: Coping strategies and policy implications. World Development, 31 (7): 1087-1102.

Smith, P. J. 2008. The terrorism ahead: Confronting transnational violence in the twenty-first century. New York: M. E. Sharpe.

Smith-Hunter, A. 2006. Women entrepreneurs across racial lines: Issues of human capital, financial capital and network structures. Cheltenham: Edward Elgar.

Stock, J. H., \& Yogo, M. 2004. Testing for weak instruments in linear IV regression. Working Paper, Department of Economics, Harvard University, Cambridge, MA.

Tang, C. S. 2006. Positive and negative postdisaster psychological adjustment among adult survivors of the Southeast Asian earthquake-tsunami. Journal of Psychosomatic Research, 61 (5): 699-705.

Tedeschi, R. G., \& Calhoun, L. G. 2004. Posttraumatic growth: Conceptual foundations and empirical evidence. Psychological Inquiry, 15 (1): 1-18.

Tennen, H., \& Affleck, G. 1998. Personality and transformation in the face of adversity. In R. G. Tedeschi, C. L. Park, \& L. G. Calhoun (Eds) Posttraumatic growth: Positive changes in the aftermath of crisis: 65-98. Mahwah, NJ: Lawrence Erlbaum Associates.

Tung, R. L., \& van Witteloostuijn, A. 2008. From the editors: What makes a study sufficiently international? Journal of International Business Studies, 39 (1): 180-183.

United Nations Department of Economic and Social Affairs. 2004. World urbanization prospects: The 2003 revision. New York: UNESA Population Division.

United Nations Habitat. 2003. The challenge of slums: Global report on human settlements 2003. London: Earthscan. 
Val, E. B., \& Linley, P. A. 2006. Posttraumatic growth, positive changes, and negative changes in Madrid residents following the March 11, 2004, Madrid train bombings. Journal of Loss and Trauma, 11 (5): 409-424.

Van der Sluis, J., van Praag, C. M., \& Vijverberg, W. 2005. Entrepreneurship selection and performance: A meta-analysis of the impact of education in developing countries. World Bank Economic Review, 19 (2): 225-261.

Vázquez, C., Cervellón, P., Pérez-Sales, P., Vidales, D., \& Gaborit, M. 2005. Positive emotions in earthquake survivors in El Salvador (2001). Journal of Anxiety Disorders, 19 (3): 313-328.

Vázquez, C., Pérez-Sales, P., \& Hervás, G. 2008. Positive effects of terrorism and posttraumatic growth: An individual and community perspective. In S. Joseph \& P. A. Linley (Eds) Trauma, recovery, and growth: Positive psychological perspectives on posttraumatic stress: 63-91. Hoboken, NJ: Wiley.

Vrana, S., \& Lauterbach, D. 1994. Prevalence of traumatic events and post-traumatic psychological symptoms in a nonclinical sample of college students. Journal of Traumatic Stress, 7 (2): 289-302.

Walsh, J. P., Kress, J. C., \& Beyerchen, K. W. 2005. Promises and perils at the bottom of the pyramid: Book review of C. K. Prahalad. The fortune at the bottom of the pyramid: Eradicating poverty through profits. Administrative Science Quarterly, 50 (3): 473-482.

Waugh, C. E., Fredrickson, B. L., \& Taylor, S. F. 2008. Adapting to life's slings and arrows: Individual differences in resilience when recovering from an anticipated threat. Journal of Research in Personality, 42 (4): 1031-1046.

Webb, J. W., Tihanyi, L., Ireland, D., \& Sirmon, D. G. 2009. You say illegal, I say legitimate: Entrepreneurship in the informal economy. Academy of Management Review, 34 (3): 492-510.

Weiser, J., Kahane, M., Rochlin, S., \& Landis, J. 2006. Untapped: Creating value in underserved markets. San Francisco, CA: Berrett-Koehler Publishers.

Wenger, A., \& Möckli, D. 2003. Conflict prevention: The untapped potential of the business sector. London: Lynne Rienner Publishers.

Westphal, M., \& Bonanno, G. A. 2007. Posttraumatic growth and resilience to trauma: Different sides of the same coin or different coins? Applied Psychology, 56 (3): 417-427.

Williams, O. F. 2008. Peace through commerce: Responsible corporate citizenship and the ideals of the United Nations Global Compact. South Bend, IN: University of Notre Dame Press.

Wilson, C., \& Wilson, P. 2006. Make poverty business: Increase profits and reduce risks by engaging with the poor. Sheffield: Greenleaf Publishing.

Wooldridge, J. M. 2002. Econometric analysis of cross section and panel data. Cambridge, MA: MIT Press.

Wooldridge, J. M. 2006. Introductory econometrics: A modern approach, (3rd ed.) Mason, OH: Thomson-South Western. 
World Bank (Urban Development Unit, South Asia Region). 2007. Dhaka: Improving living conditions for the urban poor, Report No. 35824-BD. http://www.auhn.org/download/wb-.pdf. Accessed 15 September 2009.

Wright, M., Filatotchev, I., Hoskisson, R., \& Peng, M. 2005. Strategy research in emerging economies: Challenging the conventional wisdom. Journal of Management Studies, 42 (1): 1-34.

Yunus, M. 1998. Poverty alleviation: Is economics any help? Lessons from the Grameen Bank experience. Journal of International Affairs, 52 (1): 47-65.

Zahra, S. A., Ireland, R. D., \& Hitt, M. A. 2000. International expansion by new venture firms: International diversity, mode of market entry, technological learning and performance. Academy of Management Journal, 43 (5): 925-950. 


\section{Table 1 - Zero-order correlations}

\begin{tabular}{|c|c|c|c|c|c|c|c|c|c|c|c|c|c|c|c|c|}
\hline & Mean & s.d. & 1 & 2 & 3 & 4 & 5 & 6 & 7 & 8 & 9 & 10 & 11 & 12 & 13 & 14 \\
\hline 1. Income & 11.62 & 5.20 & & & & & & & & & & & & & & \\
\hline $\begin{array}{l}\text { 2. Enterprise } \\
\text { resilience }\end{array}$ & 0.478 & 0.49 & $0.032^{*}$ & & & & & & & & & & & & & \\
\hline 3. Household size & 4.896 & 1.89 & $0.129 *$ & $0.049^{*}$ & & & & & & & & & & & & \\
\hline 4. Mother age & 24.94 & 5.67 & 0.017 & $-0.025^{*}$ & $0.316^{*}$ & & & & & & & & & & & \\
\hline $\begin{array}{l}\text { 5. Sanitary } \\
\text { infrastructure }\end{array}$ & 0.99 & 0.02 & 0.014 & 0.009 & 0.004 & -0.002 & & & & & & & & & & \\
\hline $\begin{array}{l}\text { 6. Water } \\
\text { infrastructure }\end{array}$ & 0.79 & 0.40 & $0.043^{*}$ & -0.017 & $-0.037^{*}$ & $0.052^{*}$ & 0.002 & & & & & & & & & \\
\hline $\begin{array}{l}\text { 7. Household } \\
\text { accommodation }\end{array}$ & 157.9 & 94.6 & $0.154^{*}$ & -0.005 & 0.391 * & $0.114^{*}$ & 0.000 & $-0.266^{\star}$ & & & & & & & & \\
\hline $\begin{array}{l}\text { 8. Local } \\
\text { unemployment }\end{array}$ & 1.94 & 1.61 & $-0.245^{*}$ & $-0.046^{*}$ & $0.104^{\star}$ & $0.068^{*}$ & -0.002 & $0.033^{*}$ & $0.026^{*}$ & & & & & & & \\
\hline 9. Informality & 0.22 & 0.41 & $0.173^{*}$ & $0.556^{*}$ & $-0.053^{*}$ & $0.043^{*}$ & -0.001 & 0.002 & $-0.141^{*}$ & $0.068^{*}$ & & & & & & \\
\hline 10. Education & -0.01 & 0.88 & $0.264^{\star}$ & $-0.113^{\star}$ & $-0.086^{*}$ & $0.165^{\star}$ & -0.008 & $-0.070^{*}$ & $0.257^{*}$ & $-0.137^{\star}$ & $-0.284^{\star}$ & & & & & \\
\hline 11. Gender & 0.04 & 0.19 & $-0.043^{*}$ & -0.009 & $0.107^{\star}$ & $-0.021^{\star}$ & 0.004 & $-0.035^{*}$ & $0.053^{*}$ & $0.063^{\star}$ & $0.026^{*}$ & $-0.037^{\star}$ & & & & \\
\hline $\begin{array}{l}\text { 12. Level of } \\
\text { terrorism }\end{array}$ & -0.07 & 0.94 & $0.264^{*}$ & 0.029 * & $-0.106^{\star}$ & $-0.051^{\star}$ & 0.012 & $0.236^{\star}$ & $-0.237^{\star}$ & $-0.615^{*}$ & $-0.084^{\star}$ & 0.008 & $-0.072^{*}$ & & & \\
\hline $\begin{array}{l}\text { 13. Terrorism } \\
\text { outbreak }\end{array}$ & 0.20 & 0.40 & $-0.086^{\star}$ & -0.007 & 0.101 * & $0.035^{*}$ & 0.011 & $-0.404^{*}$ & 0.142 & $0.435^{*}$ & -0.006 & $-0.081^{\star}$ & $0.021^{*}$ & $0.043^{*}$ & & \\
\hline $\begin{array}{l}\text { 14. Terrorism } \\
\text { escalation }\end{array}$ & 0.40 & 0.49 & $0.276^{\star}$ & $0.027^{\star}$ & $-0.146^{*}$ & $-0.065^{*}$ & 0.007 & $0.407^{\star}$ & $-0.301^{*}$ & $-0.713^{\star}$ & $-0.072^{\star}$ & $0.036^{\star}$ & $-0.074^{\star}$ & $0.891^{\star}$ & -0.408 * & \\
\hline $\begin{array}{l}\text { 15. Terrorism } \\
\text { reduction }\end{array}$ & 0.20 & 0.40 & $-0.161^{*}$ & $-0.033^{\star}$ & $0.026^{\star}$ & $0.027^{*}$ & 0.003 & $0.225 *$ & $-0.092^{\star}$ & 0.728 & $0.067^{\star}$ & $-0.092^{*}$ & $0.055^{*}$ & $-0.630^{\star}$ & -0.250 & -0.408 \\
\hline
\end{tabular}


Table 2 - Results of instrumented variables regressions

\begin{tabular}{|c|c|c|c|c|c|c|c|}
\hline & Model I & Model 2 & Model 3 & Model 4 & Model S & Model 6 & Model 7 \\
\hline \multicolumn{8}{|l|}{ First stage (Enterprise resilience) } \\
\hline Terrorism outbreak (Hla) & $0.331^{*}$ & $-0.718^{\dagger}$ & $-0.768^{\dagger}$ & $-0.723^{\dagger}$ & $-0.719^{\dagger}$ & $-0.711^{\dagger}$ & $-0.715^{\dagger}$ \\
\hline Terrorism escalation ( $\mathrm{H} 1 \mathrm{~b})$ & -0.001 & $-1.764^{*}$ & $-1.755^{*}$ & $-1.777^{*}$ & $-1.765^{*}$ & $-1.749^{*}$ & $-1.762^{*}$ \\
\hline Terrorism reduction ( $\mathrm{H} 1 \mathrm{c})$ & $0.371^{*}$ & $0.493^{*}$ & $0.474^{*}$ & $0.497^{*}$ & $0.492^{*}$ & $0.491^{*}$ & $0.495^{*}$ \\
\hline Gender & $-0.076^{* *}$ & $-0.076^{*+}$ & $-0.090^{*}$ & $-0.073^{*+*}$ & $-0.076^{*+}$ & $-0.076^{*+}$ & $-0.073^{* *}$ \\
\hline Gender x Terrorism outbreak (H2a) & & & 0.046 & & & & \\
\hline Gender $\times$ Terrorism escalation (H2b) & & & -0.012 & & & & \\
\hline Gender $\times$ Terrorism reduction $(\mathrm{H} 2 \mathrm{c})$ & & & 0.020 & & & & \\
\hline \multicolumn{8}{|l|}{ Instruments } \\
\hline Househoid size & $0.022^{*+*}$ & $0.022 *$ & $0.022 *$ & $0.022^{* * *}$ & $0.022 *$ & $0.022 *$ & $0.022^{* * *}$ \\
\hline Mother age & -0.002 & $-0.002^{\prime}$ & $-0.002^{\dagger}$ & $-0.002^{\prime}$ & $-0.002^{\dagger}$ & $-0.002^{\prime}$ & $-0.002^{t}$ \\
\hline Sanitary infrastructure & 0.179 & $0.197^{\dagger}$ & $0.197^{\dagger}$ & $0.202^{*}$ & $0.197^{\dagger}$ & $0.196^{\dagger}$ & $0.200^{\prime}$ \\
\hline Water infrastructure & 0.069 & -0.018 & -0.018 & -0.019 & -0.018 & 0.018 & -0.019 \\
\hline Household accommodation & $0.001^{*+}$ & $0.000^{*+}$ & $0.000^{*+}$ & $0.000^{*+4}$ & $0.001 *$ & $0.000^{*+4}$ & $0.001^{* *}$ \\
\hline \multicolumn{8}{|l|}{ Recursive effects } \\
\hline Local unemployment & $-0.131^{*}$ & $-0.090^{+}$ & $-0.090^{\dagger}$ & $-0.091^{\dagger}$ & $-0.091^{+}$ & $-0.091^{\dagger}$ & -0.091 \\
\hline Informality & $0.709^{* * *}$ & $0.709 *$ & $0.709 *$ & $0.703^{* * *}$ & $0.709 *$ & $0.701^{*+*}$ & $0.695^{* * *}$ \\
\hline Education & $0.021^{*}$ & $0.022^{*}$ & $0.022^{*}$ & $0.022^{*}$ & $0.022^{*}$ & $0.024^{*}$ & $0.024^{*}$ \\
\hline Informality $\times$ Education & & & & & & $-0.020^{\prime}$ & $-0.020^{t}$ \\
\hline Level of terrorism & & $0.928^{*}$ & $0.929^{*}$ & $0.949^{*}$ & $0.928^{*}$ & $0.920^{*}$ & $0.942^{*}$ \\
\hline Level of terrorism $\times$ Informality & & & & $-0.064^{* * *}$ & & & $-0.065^{* *}$ \\
\hline Level of terrorism $\times$ Education & & & & & 0.008 & & -0.001 \\
\hline $\begin{array}{l}\text { Level of temorism } \times \text { Education } \times \\
\text { informality }\end{array}$ & & & & & & & 0.001 \\
\hline F test (first stage) & $35.00^{*+4}$ & $20.31 \cdots$ & $17.88^{*+*}$ & $20.72 *+\cdots$ & $20.52 *+*$ & $19.89^{*+*}$ & $20.44^{*+*}$ \\
\hline \multicolumn{8}{|l|}{ Second stage (Income) } \\
\hline Enterprise resilience (H3) & $19.961 \cdots$ & $17.306^{* * *}$ & $17.231^{\cdots+*}$ & $16.821^{* *}$ & $17.036^{* * *}$ & $17.211^{\cdots+*}$ & $16.629 * *$ \\
\hline Local unemployment & -0.190 & 0.000 & -0.000 & -0.004 & 0.015 & -0.002 & -0.000 \\
\hline Informality & $-15.000^{*+*}$ & $-13.061^{* * *}$ & $-13.009^{* * t}$ & $-12.605^{* * *}$ & -12.858 & $-13.133^{* *}$ & $-12.621^{* * *}$ \\
\hline Education & $0.759^{*+4}$ & $0.887^{*+*}$ & $0.889^{*+*}$ & $0.896^{* * *}$ & $0.888^{+.+4}$ & $0.935^{*+*}$ & $0.945^{*+*}$ \\
\hline Level of terrorism & & $0.707^{* *}$ & $0.709^{* *}$ & 0.468 & $0.737^{\text {****}}$ & $0.709^{*+4}$ & $0.504^{*}$ \\
\hline Level of terrorism x Informality $(\mathrm{H} 4)$ & & & & $1.147^{* * *}$ & & & $1.112^{*+*}$ \\
\hline Level of terrorism $\times$ Education $(\mathrm{H} 5)$ & & & & & -0.259 & & -0.133 \\
\hline Informality $\times$ Education & & & & & & -0.365 & $-0.374^{\dagger}$ \\
\hline $\begin{array}{l}\text { Level of terrorism } \times \text { Informality } \times \\
\text { Education }\end{array}$ & & & & & & & 0.125 \\
\hline$R^{2}$ & 0.50 & 0.60 & 0.60 & 0.62 & 0.61 & 0.60 & 0.62 \\
\hline Hansen / p-value & 12.64 & 14.65 & 15.05 & 14.99 & 15.16 & 14.56 & 15.01 \\
\hline
\end{tabular}

"Stage 2 models also include five dummy variables to control for growing season.

Two-tailed tests: ${ }^{\dagger} p<0.10 ; " p<0.05 ; " * p<0.01 ; * * p<0.001$.

Instruments for Enterprise Resilience and Recursive effects are shown in italics. 
Table 3 - Post-hoc probing with terrorism conditions

\begin{tabular}{|c|c|c|c|c|}
\hline & Terronism absence & Terronism outbreak & Terrorism escalation & Temorism reduction \\
\hline \multicolumn{5}{|l|}{ First stage (Enterprise resilience) } \\
\hline Gender $(\mathrm{H} 2 \mathrm{a}, \mathrm{H} 2 \mathrm{~b}, \mathrm{H} 2 \mathrm{c})$ & $-0.086^{*}$ & -0.037 & $-0.087^{*}$ & $-0.064^{\dagger}$ \\
\hline \multicolumn{5}{|l|}{ Instruments } \\
\hline Househoid Size & $0.028^{* * *}$ & $0.021^{* * *}$ & $0.021^{* * *}$ & $0.014^{*}$ \\
\hline Mother age & $-0.005^{*}$ & -0.002 & 0.000 & -0.001 \\
\hline Water infrastructure & $-0.154^{*+*}$ & $-0.072^{*+*}$ & -0.010 & 0.025 \\
\hline Household accommodation & $0.000^{\dagger}$ & $0.001^{* *}$ & 0.000 & $0.001 \cdots$ \\
\hline \multicolumn{5}{|l|}{ Recursive effects } \\
\hline Informality & $0.720^{*+*}$ & $0.697^{*+4}$ & $0.626^{* * *}$ & $0.784^{*+*}$ \\
\hline Education & 0.012 & $0.085^{*+*}$ & 0.008 & 0.006 \\
\hline Informality $\times$ Education & -0.017 & $-0.055^{* *}$ & -0.008 & -0.007 \\
\hline F test (first stage) & $20.35 \cdots$ & $8.38 \cdots$ & $6.54 * *$ & $5.96^{* * *+}$ \\
\hline \multicolumn{5}{|l|}{ Second stage $e^{a}$ (Income) } \\
\hline Enterprise resilience (H3) & $15.436^{* * *}$ & $13.054^{\text {****}}$ & $24.698^{\text {t*** }}$ & $23.024^{* * *}$ \\
\hline Informality (H4) & $-12.781^{* * *}$ & $-10.125^{* * *}$ & $-16.591^{* * *}$ & $-19.139 *$ \\
\hline Education (H5) & $1.411^{* * *}$ & 0.438 & $0.933^{\text {****}}$ & $1.266^{* * *}$ \\
\hline Education $\times$ Informal & $-1.094^{* *}$ & 0.017 & -0.437 & -0.366 \\
\hline$R^{2}$ & 0.64 & 0.69 & 0.35 & 0.35 \\
\hline Hansen / p-value & 8.47 & 0.47 & 5.37 & 4.04 \\
\hline
\end{tabular}

"Stage 2 models also include five dummy variables to control for growing season. Two-tailed tests: ${ }^{\dagger} p<0.10, " p<0.05 ; " p<0.01 ; \cdots " \cdots<0.001$.

Instruments for Enterprise Resilience and Recursive effects are shown in italics. 


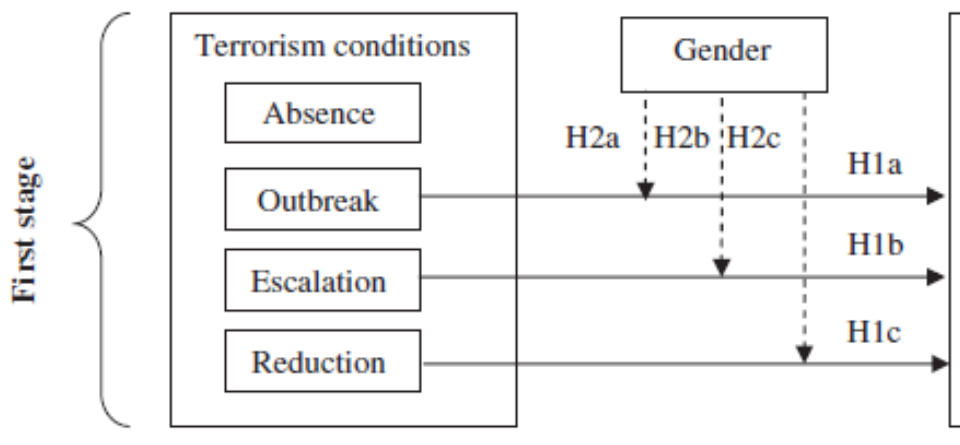

Enterprise resilience

Instruments

Household needs

Household size

Mother age

Household resourcefulness

Water infrastructure

Sanitary infrastructure

Household accommodation

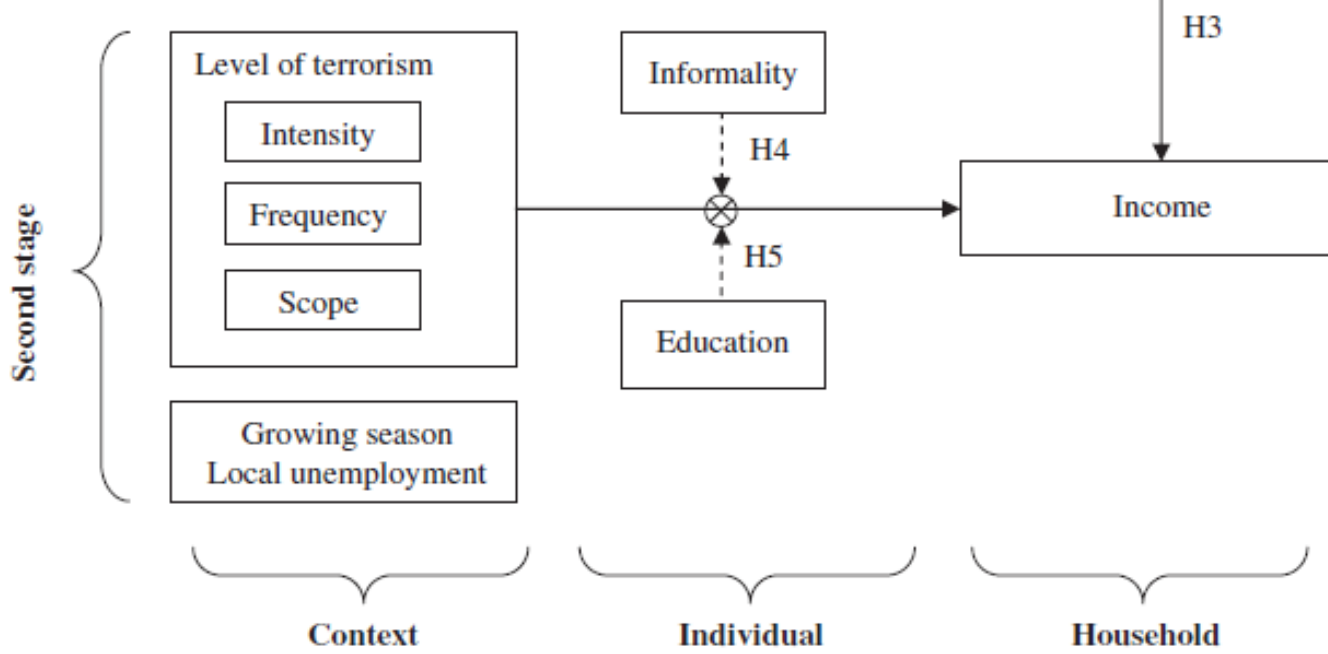

Figure 1 - A two-stage model of enterprise resilience under terrorism 

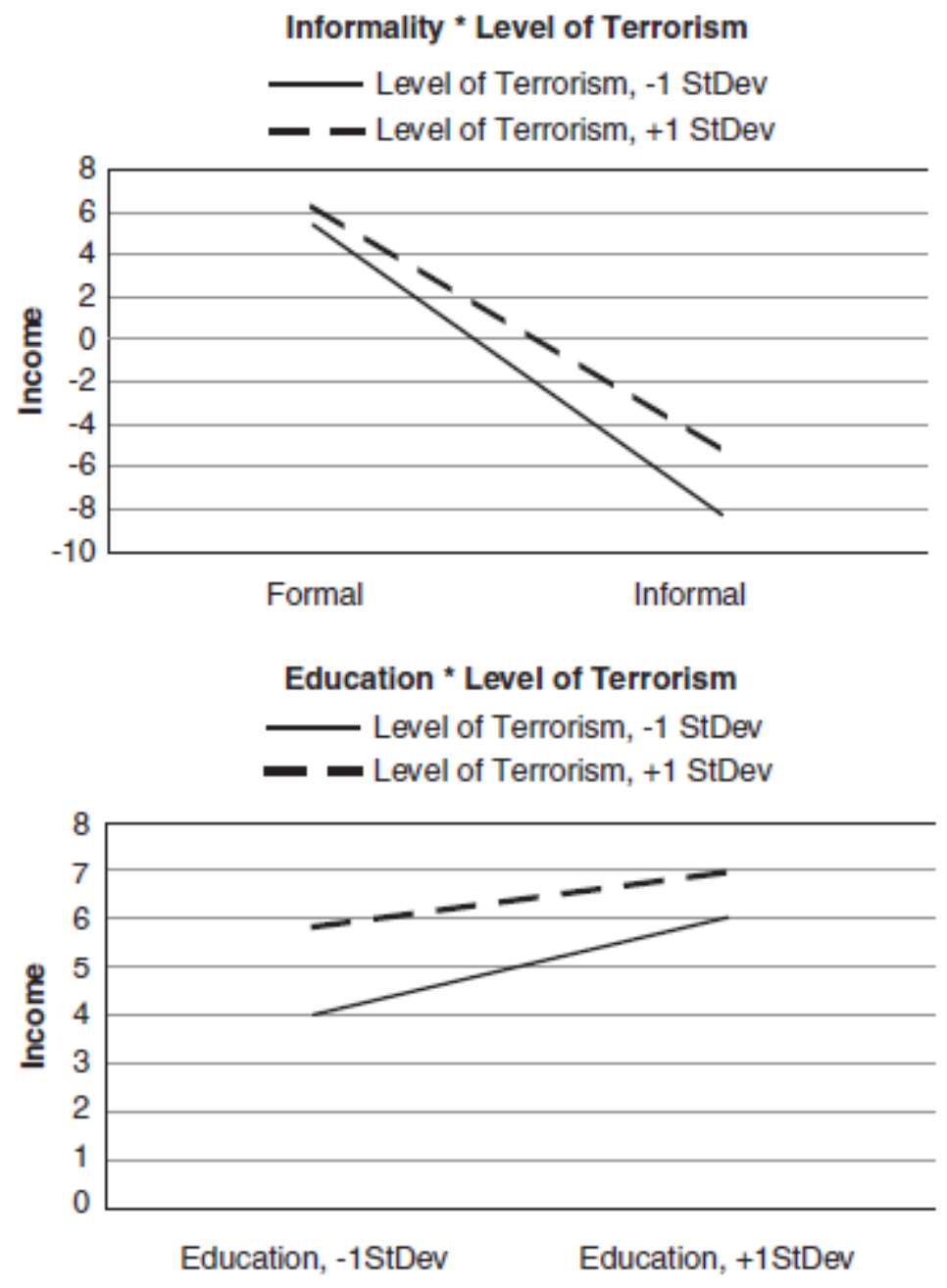

Figure 2 - Interaction effects 


\section{APPENDIX}

\begin{tabular}{|c|c|c|c|c|c|c|c|c|}
\hline $\begin{array}{l}2001- \\
2003\end{array}$ & $\begin{array}{l}2003- \\
2005\end{array}$ & $\begin{array}{l}\text { Terrorism } \\
\text { condition }\end{array}$ & $\begin{array}{l}\text { Level of } \\
\text { terrorism }\end{array}$ & Cities (6) & $\begin{array}{l}\text { Slum wards } \\
\text { (32) }\end{array}$ & $\begin{array}{l}\text { Slums } \\
(628)\end{array}$ & $\begin{array}{l}\text { Households } \\
(1500 \times 6)^{\mathrm{b}}\end{array}$ & $\begin{array}{c}\text { Population (2001 } \\
\text { census) }\end{array}$ \\
\hline \multirow[t]{4}{*}{ No } & No & Absence & -1.009 & Rajshahi & 3 & 50 & 150 & 0.39 \\
\hline & & & -1.009 & Barisal & 3 & 49 & 150 & 0.22 \\
\hline & Yes & Outbreak & 0.079 & Sylhet & 3 & 60 & 150 & 0.32 \\
\hline & & & -0.054 & Khulna & 3 & 57 & 150 & 0.78 \\
\hline \multirow[t]{2}{*}{ Yes } & Yes & Escalation & 0.952 & Dhaka & 12 & 248 & 600 & 5.40 \\
\hline & No & Reduction & -1.245 & Chittagong & 8 & 164 & 300 & 1.99 \\
\hline
\end{tabular}

http://en.wikipedia. org/wiki/List of cities in Bangladesh. Accessed 15 October 2008

Households in urban slums, sampled by the Nutritional Surveillance Project (NSP) of Helen Keller International (HKI) in Bangladesh, February 2005-January 2006.

chttp://www.bbs.gov.bd/dataindex/stat_bangladesh.pdf. Accessed 7 July 2009.

\footnotetext{
' The authors thank Paul Beamish for his insights and guidance throughout this project. Our colleagues Tima Bansal, Geoff Kistruck, Srinivas Sridharan, and Stewart Thornhill also offered helpful suggestions on prior versions of the manuscript. We are grateful to the Special Issue editors and reviewers, and especially to our action editor, Mary Ann Von Glinow, for their feedback during the review process. Financial support was provided by the Social Sciences and Humanities Research Council, a 2007-2008 Canadian-African Capacity Building Grant for Private Sector Development Research in Africa co-funded by the Investment Climate and Business Environment Research Fund (ICBE RF), The International Development Research Centre (IDRC) and TrustAfrica (Ford Foundation), and the Richard Ivey School of Business at The University of Western Ontario. A prior version of the manuscript was presented at the 2009 Academy of Management Meetings in Chicago, where it received the Entrepreneurship division nomination for the all-academy Carolyn Dexter award.
} 